\title{
Stappia marina sp. nov., a marine bacterium isolated from the Yellow Sea
}

\author{
Correspondence \\ Yong-Ha Park \\ yhpark@kribb.re.kr
}

\author{
Byung-Chun Kim, ${ }^{1}$ Ja Ryeong Park, ${ }^{1,2}$ Jin-Woo Bae, ${ }^{1}$ Sung-Keun Rhee, ${ }^{1}$ \\ Kyoung-Ho Kim, ${ }^{1}$ Jong-Won $\mathrm{Oh}^{2}$ and Yong-Ha Park ${ }^{1}$ \\ ${ }^{1}$ Korea Research Institute of Bioscience and Biotechnology, 52 Oeundong, Yusong, Daejeon \\ 305-333, Republic of Korea \\ ${ }^{2}$ Department of Biotechnology, Yonsei University, Seoul 120-749, Republic of Korea
}

A Gram-negative, aerobic and halophilic bacterium designated strain mano $18^{\top}$ was isolated from a tidal flat area of Dae-Chun, Chung-Nam, Korea. This strain was motile by means of polar flagella, occasionally forming rosette-like aggregates, reduced nitrate to nitrite, required sodium ions for growth, exhibited catalase and oxidase activities and contained $Q-10$ as the major quinone and $\mathrm{C}_{18: 1} \omega 7 \mathrm{C}$ as the dominant cellular fatty acid. Analysis of the $16 \mathrm{~S}$ rRNA gene sequence revealed that this strain is affiliated with a cluster within the Alphaproteobacteria. Strain mano $18^{\top}$ synthesized bacteriochlorophyll under aerobic conditions. The $16 \mathrm{~S}$ rRNA gene sequence similarity between strain mano $18^{\top}$ and the most closely related species, Stappia aggregata DSM $13394^{\top}$, was $98.5 \%$. Levels of DNA-DNA relatedness between strain mano $18^{\top}$ and the type strains of $S$. aggregata and Stappia stellulata were respectively $6 \cdot 2-11 \cdot 2$ and $3 \cdot 3-7 \cdot 6 \%$. Strain mano $18^{\top}$, like other Stappia strains, possesses carbon monoxide dehydrogenase genes. The results of DNA-DNA hybridization and the polyphasic data confirmed that strain mano $18^{\top}$ can be considered to represent a novel taxon in the genus Stappia. The name Stappia marina sp. nov. is proposed for the tidal flat isolate; the type strain is strain mano18 $8^{\top}(=$ KCTC $12288^{\top}=$ DSM $17023^{\top}$ ).

The genus Agrobacterium has been reported to include terrestrial and plant-pathogenic species and marine species (Rüger \& Höfle, 1992; Stapp \& Knösel, 1954). In a study of marine star-shaped-aggregate-forming bacteria, Rüger \& Höfle (1992) concluded that 'Agrobacterium aggregatum' (Ahrens, 1968) was a later heterotypic synonym of Agrobacterium stellulatum (Stapp \& Knösel, 1954), which had nomenclatural priority. Later phylogenetic studies based on $16 \mathrm{~S}$ rRNA gene sequences suggested that the marine species of the genus Agrobacterium have no relation to the terrestrial Agrobacterium species; therefore, the taxonomic position of the marine subdivision of Agrobacterium was reassessed and a proposal was made to transfer two species belonging to Agrobacterium to a new genus as Stappia aggregata and Stappia stellulata (Uchino et al., 1998). All known strains of the genus Stappia have been shown to oxidize carbon monoxide (CO) and to possess the gene for $\mathrm{CO}$ dehydrogenase $(\operatorname{coxL})$ in a survey of the diversity of aerobic CO oxidizers (King, 2003).

Published online ahead of print on 7 October 2005 as DOI 10.1099/ ijs.0.63735-0.

The GenBank/EMBL/DDBJ accession numbers for the 16S rRNA and form I and form II coxL gene sequences of strain mano $18^{\top}$ are respectively AY628423, AY753548 and AY753549.
Recently, a number of bacterial strains have been isolated in a tidal flat area as part of a study aimed at understanding the diversity of micro-organisms and their function in a tidal flat ecosystem. Many of them have been identified as phylogenetically novel micro-organisms (Yoon et al., 2003a, b, c). In this study, we describe a Stappia-like strain, mano $18^{\mathrm{T}}$, which was isolated from a tidal flat area of the Yellow Sea, Korea. The organism was considered to be Stappia-like on the basis of $16 \mathrm{~S}$ rRNA gene sequence comparison. Accordingly, the aim of present work was to elucidate the taxonomic position of strain mano $18^{\mathrm{T}}$ by means of phenotypic, genetic and chemotaxonomic analyses.

Strain mano $18^{\mathrm{T}}$ was isolated from a sample of a tidal flat obtained in Dae-Chun, Chung-Nam, Korea ( $36^{\circ} 17^{\prime} 45 \cdot 2^{\prime \prime} \mathrm{N}$ $126^{\circ} 31^{\prime} 9 \cdot 5^{\prime \prime} \mathrm{E}$ ) by using the dilution plating technique on marine agar 2216 (MA; Difco). The strain was routinely grown at $25^{\circ} \mathrm{C}$ for 3 days. S. aggregata DSM $13394^{\mathrm{T}}$ and $S$. stellulata DSM $5886^{\mathrm{T}}$, obtained from the DSMZ, were grown under the same conditions and used as reference strains. Morphology of live cells and the presence of flagella were investigated by using light microscopy (Nikon E600) and transmission electron microscopy (TEM). For TEM observation, cells from exponentially grown culture were negatively stained with $1 \%(\mathrm{w} / \mathrm{v})$ phosphotungstic acid. After air drying, the grid was examined by using a model H-7600 
transmission electron microscope (Hitachi). Anaerobic growth was tested by using a BBL GasPak Pouch (Becton Dickinson) on MA supplemented with nitrate. Sodium ion requirements were determined by comparing growth on $\mathrm{BM}$ medium (Baumann et al., 1971) and modified BM medium containing potassium ions in place of sodium ions and by investigating growth in trypticase soy broth without $\mathrm{NaCl}$. Growth at various $\mathrm{NaCl}$ concentrations was investigated in marine broth 2216 (MB; Difco) or trypticase soy broth (Difco). API 20 NE test strips (bioMérieux) were used for analysing biochemical and physiological traits of bacterial strains and standard microbiological methods were used for studying Gram staining, motility and catalase and oxidase activities (Smibert \& Krieg, 1994).

Isoprenoid quinones of strain mano $18^{\mathrm{T}}$ was extracted from $100 \mathrm{mg}$ freeze-dried cells according to Collins \& Jones (1981) and purified by preparative TLC (silica gel F254; Merck). The ubiquinone fraction was analysed by HPLC (Hitachi L-5000) equipped with a reversed-phase column (YMC pack ODS-AM; YMC Co.) as described by Shin et al. (1996). Bacterial strains grown on MA plates at $25^{\circ} \mathrm{C}$ for 5 days were used for fatty acid methyl ester (FAME) analysis. FAMEs were extracted and prepared according to the standard protocol of the MIDI/Hewlett Packard Microbial Identification System (Sasser, 1990). The DNA G+C content was determined by the method of Tamaoka \& Komagata (1984). Chromosomal DNA was extracted and purified according to the method described by Sambrook et al. (1989). DNA was hydrolysed and the resultant nucleotides were analysed by HPLC using a reversed-phase column (Supelcosil LC-18-S; Supelco). The 16S rRNA gene was amplified by PCR using two universal primers as described previously (Yoon et al., 1998). Sequencing of the amplified $16 \mathrm{~S}$ rRNA gene and phylogenetic analysis were performed as described by Yoon et al. (2003a). DNA-DNA hybridization was based on the method described by Kusuda et al. (1991) and Willcox (1996). DNA was transferred to a nylon membrane (Hybond- $\mathrm{N}^{+}$; Amersham). The membrane was incubated for $1 \mathrm{~h}$ at $40^{\circ} \mathrm{C}$ for prehybridization and then for $12 \mathrm{~h}$ at $40^{\circ} \mathrm{C}$ for hybridization. A DIG High Prime DNA Labelling and Detection starter kit II (Roche Molecular Biochemicals) was used for the detection of DNA. After washing, the membrane was exposed to autoradiography film (Hyperfilm-ECL; Amersham) for $10 \mathrm{~min}$ and signal intensities were determined using the TINA 2.0 program (Lee et al., 2003). The signal produced by self-hybridization was taken as $100 \%$, and relative intensities of genomic DNAs of other strains were determined to be the percentage similarity.

The coxL gene of strain mano $18^{\mathrm{T}}$ was amplified according to the method of King (2003). Two forward primers, OMPf [5' GGCGGCTT(C/T)GG(C/G)AA(C/G)AAGGT-3'] and BMSf [5'-GGCGGCTT(C/T)GG(C/G)TC(C/G)AAGAT-3'], and a reverse primer, $\mathrm{O} / \mathrm{Br}\left[5^{\prime}-(\mathrm{C} / \mathrm{T}) \mathrm{TCGA}(\mathrm{T} / \mathrm{C})\right.$ GATCATCGG$(\mathrm{A} / \mathrm{G})$ TTGA-3'], were designed on the basis of conserved motifs of gene sequences for the large subunit of authentic CO dehydrogenases (King, 2003). Primer pairs OMPf and
$\mathrm{O} / \mathrm{Br}$ or $\mathrm{BMSf}$ and $\mathrm{O} / \mathrm{Br}$ were used for amplification of the form I and form II large subunit genes of CO dehydrogenase, respectively.

The production of bacteriochlorophyll $a(\mathrm{BChl} a)$ by strain mano $18^{\mathrm{T}}$ was investigated by PCR amplification of a phototrophism-related gene ( $p u f M)$. Primers pufMF (5'CGCACCTGGACTGGAC-3'; Achenbach et al., 2001) and pufMR [5'-CCAT(G/C)GTCCAGCGCCAGAA-3'; Beja et al., 2002] were used for PCR amplification of the pufLM gene. Extracted genomic DNA of strain mano $18^{\mathrm{T}}$ was used as the PCR template. The PCR mixture contained $1.5 \mathrm{mM}$ $\mathrm{MgCl}_{2}, 0 \cdot 25 \mu \mathrm{M}$ each dNTP, $5 \mathrm{U}$ Taq DNA polymerase, $0.5 \mu \mathrm{M}$ each primer and $10 \mathrm{ng}$ template DNA in a total volume of $20 \mu \mathrm{l}$ (Bioneer). PCR was performed in a thermocycler (iCycler; Bio-Rad) with an initial denaturation step at $95^{\circ} \mathrm{C}$ for $4 \mathrm{~min}$ followed by 30 cycles of denaturation at $95^{\circ} \mathrm{C}$ for $1 \mathrm{~min}$, annealing at $47^{\circ} \mathrm{C}$ for $40 \mathrm{~s}$ and extension at $72^{\circ} \mathrm{C}$ for $1.5 \mathrm{~min}$ and a final extension at $72^{\circ} \mathrm{C}$ for $7 \mathrm{~min}$. The amplified DNA was separated by agarose gel electrophoresis ( $1 \%$ agarose in $1 \times \mathrm{TAE})$, stained with ethidium bromide, viewed by UV illumination and photographed.

Cells of strain mano $18^{\mathrm{T}}$ were Gram-negative, regular and club shaped. They occurred singly, in irregular clusters or in star-like aggregates or rosette-like aggregates (Fig. 1). However, star-shaped aggregate formation could not always be observed. It seems to be dependent on the physiological state of the cells (Suzuki et al., 2000). Strain mano18 ${ }^{\mathrm{T}}$ has been grown at $25-30{ }^{\circ} \mathrm{C}$ and needed sodium ions for growth. Growth occurs in the presence of 3-6\% (w/v) $\mathrm{NaCl}$. Optimum growth of strain mano $18^{\mathrm{T}}$ occurred at $25^{\circ} \mathrm{C}$ and in $3 \%(\mathrm{w} / \mathrm{v}) \mathrm{NaCl}$. The physiological and biochemical properties of strain mano $18^{\mathrm{T}}$ are summarized in Table 1. A partial $16 \mathrm{~S}$ rRNA gene sequence (1355 bp) was determined from strain mano $18^{\mathrm{T}}$. The result of a BLAST search indicated that the isolate was a member of the Alphaproteobacteria and was closely related to several marine bacteria. The $16 \mathrm{~S}$

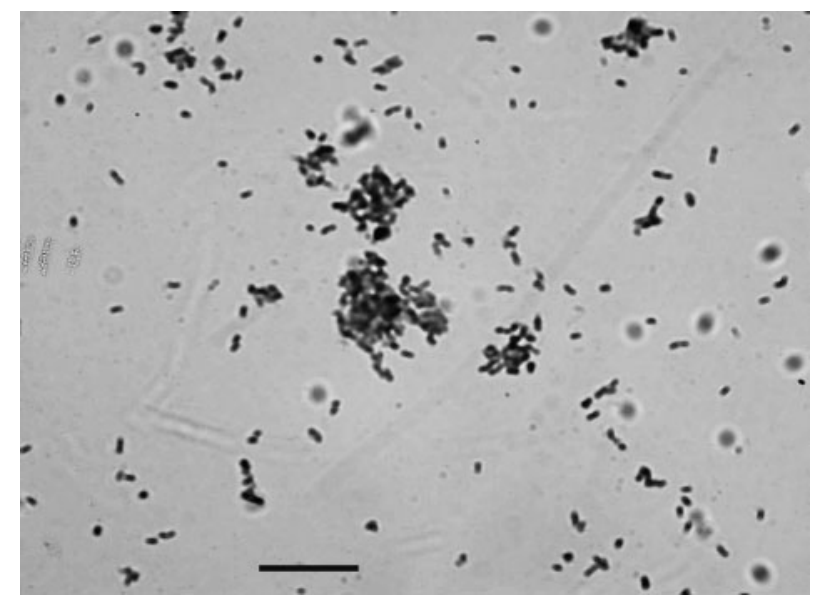

Fig. 1. Light micrograph of strain mano $18^{\top}$ showing rosettelike-aggregate formation. Bar, $10 \mu \mathrm{m}$. 
Table 1. Characteristics that differentiate strain mano18 from other Stappia species and Roseibium hamelinense

Strains: $1, R$. hamelinense OCh $368^{\mathrm{T}} ; 2$, mano $18^{\mathrm{T}} ; 3$, S. aggregata DSM $13394^{\mathrm{T}} ; 4$, S. stellulata DSM $5886^{\mathrm{T}}$. +, Positive; -, negative; $\mathrm{W}$, weakly positive; ND, no data. Data for $R$. hamelinense were taken from Suzuki et al. (2000). Cells of all strains are aerobic, motile rods that stain Gram-negative. All strains require $\mathrm{NaCl}$ and grown in 3 and $6 \% \mathrm{NaCl}$. All strains reduce nitrate to nitrite. All Stappia strains are positive for catalase and oxidase and negative for indole production from tryptophan, arginine dihydrolase, gelatin hydrolysis and acid production from glucose. For determination of utilization of carbon sources, cultures were incubated for 7 days at $25^{\circ} \mathrm{C}$.

\begin{tabular}{|lcccc|}
\hline Characteristic & $\mathbf{1}$ & $\mathbf{2}$ & $\mathbf{3}$ & $\mathbf{4}$ \\
\hline Growth in $10 \% \mathrm{NaCl}$ & + & $\mathrm{W}$ & + & $\mathrm{W}$ \\
Reduction of nitrite to $\mathrm{N}_{2}$ & - & - & + & - \\
Urease & - & + & + & - \\
Aesculin hydrolysis & $\mathrm{ND}$ & + & + & - \\
$\beta$-Galactosidase & $\mathrm{ND}$ & + & + & - \\
Utilization of carbon sources & & & & \\
Glucose & + & - & + & - \\
Arabinose & $\mathrm{ND}$ & - & + & - \\
Mannose & $\mathrm{ND}$ & $\mathrm{W}$ & + & - \\
Mannitol & $\mathrm{ND}$ & - & + & - \\
N-Acetylglucosamine & $\mathrm{ND}$ & - & + & - \\
Maltose & $\mathrm{ND}$ & - & + & - \\
Gluconate & $\mathrm{ND}$ & - & + & - \\
Caprate & $\mathrm{ND}$ & - & - & - \\
Adipate & $\mathrm{ND}$ & - & $\mathrm{w}$ & $\mathrm{W}$ \\
Malate & $\mathrm{ND}$ & + & + & $\mathrm{W}$ \\
Citrate & $\mathrm{ND}$ & - & + & - \\
Phenylacetate & $\mathrm{ND}$ & - & $\mathrm{w}$ & - \\
& & & & \\
\hline
\end{tabular}

rRNA gene sequence of strain mano $18^{\mathrm{T}}$ showed the highest similarity to that of S. aggregata DSM $13394^{\mathrm{T}}(98 \cdot 5 \%)$; the next highest similarity was observed to members of the genus Roseibium (97\%) and S. stellulata DSM 5886 ${ }^{\mathrm{T}}$ (95\%). $16 \mathrm{~S}$ rRNA gene sequence alignment and phylogenetic tree construction (Fig. 2) were conducted by using CLUSTAL X software (Thompson et al., 1997). DNA-DNA hybridization studies were carried out between strain mano $18^{\mathrm{T}}$ and closely related strains selected on the basis of their 16S rRNA gene sequence similarities and phylogenetic positions. The low DNA-DNA relatedness between strain mano $18^{\mathrm{T}}$ and $S$. aggregata DSM $13394^{\mathrm{T}}(6 \cdot 2-11 \cdot 2 \%)$ and S. stellulata DSM $5886^{\mathrm{T}}(3 \cdot 3-7 \cdot 6 \%)$ confirmed that strain mano $18^{\mathrm{T}}$ represents a novel species.

Ubiquinone 10 (Q-10) was the predominant isoprenoid quinone in strain mano $18^{\mathrm{T}}$ and the $\mathrm{G}+\mathrm{C}$ content of strain mano $18^{\mathrm{T}}$ was $59 \cdot 7 \mathrm{~mol} \%$. Unsaturated fatty acids including $\mathrm{C}_{18: 1} \omega 7 c(58 \cdot 47 \%)$ together with $\mathrm{C}_{20: 1} \omega 7 c(7 \cdot 80 \%), 11-$ methyl $\mathrm{C}_{18: 1} \omega 7 c(9 \cdot 08 \%), \mathrm{C}_{17: 1} \omega 8 c(0.55 \%)$ and $\mathrm{C}_{18: 1} \omega 9 c$ $(0 \cdot 23 \%)$ were the most abundant. Small amounts of saturated fatty acids $\mathrm{C}_{18: 0}(8.03 \%), \mathrm{C}_{19: 0}$ cyclo $\omega 8 c$ $(3.56 \%)$ and $\mathrm{C}_{16: 0}(1.65 \%)$ were also detected. The fatty

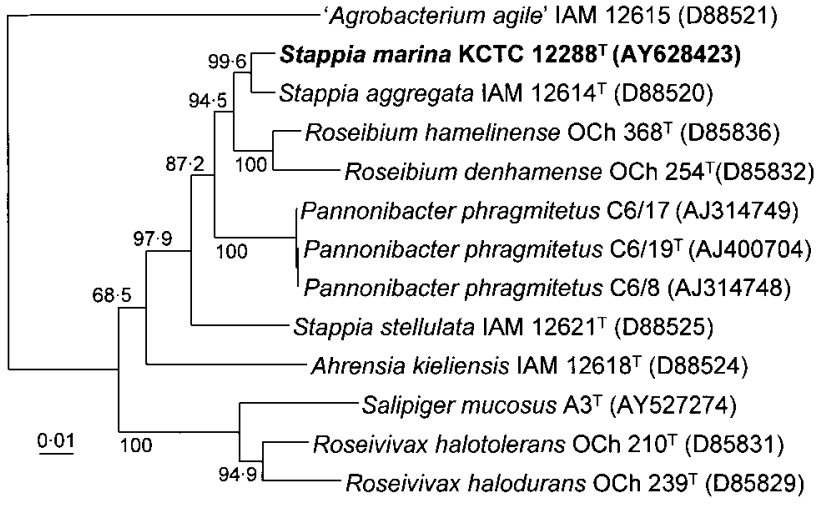

Fig. 2. Neighbour-joining tree based on 16S rRNA gene sequences showing the phylogenetic position of strain mano18 ${ }^{\top}$ within closely related strains in the family Rhodobacteraceae. Bootstrap values (1000 replications) are shown as percentages at each node only if they are $50 \%$ or greater. Bar, 0.01 substitutions per nucleotide position. 'Agrobacterium agile' IAM 12615 was used as the outgroup.

acid composition was most similar to that observed in the genus Stappia (Table 2) and clearly differentiated the isolate from other phylogenetically related genera (data not

Table 2. Cellular fatty acid compositions of strain mano18 ${ }^{\top}$ and type strains of Stappia species

Strains: 1 , mano18 ${ }^{\mathrm{T}} ; 2$, S. aggregata DSM $13394^{\mathrm{T}} ; 3$, S. stellulata DSM $5886^{\mathrm{T}}$. Values are percentages of total fatty acids; fatty acids representing less than $0.5 \%$ in all strains were omitted. - , Not detected.

\begin{tabular}{|lccc|}
\hline Fatty acid & $\mathbf{1}$ & $\mathbf{2}$ & $\mathbf{3}$ \\
\hline Saturated fatty acids & & & \\
$\mathrm{C}_{16: 0}$ & $1 \cdot 65$ & $1 \cdot 15$ & $3 \cdot 65$ \\
$\mathrm{C}_{18: 0}$ & $8 \cdot 03$ & $3 \cdot 09$ & $2 \cdot 77$ \\
$\mathrm{C}_{19: 0}$ cyclo $\omega 8 c$ & $3 \cdot 56$ & - & $3 \cdot 22$ \\
Unsaturated fatty acids & & & \\
$\mathrm{C}_{17: 1} \omega 8 c$ & $0 \cdot 55$ & $0 \cdot 83$ & $0 \cdot 14$ \\
$\mathrm{C}_{18: 1} \omega 7 c$ & $58 \cdot 47$ & $76 \cdot 64$ & $61 \cdot 97$ \\
$\mathrm{C}_{18: 1} \omega 9 c$ & $0 \cdot 23$ & $0 \cdot 29$ & $0 \cdot 70$ \\
$\mathrm{C}_{20: 1} \omega 7 c$ & $7 \cdot 80$ & $4 \cdot 72$ & $0 \cdot 22$ \\
$11-$ Methyl $\mathrm{C}_{18: 1} \omega 7 c$ & $9 \cdot 08$ & $6 \cdot 95$ & $20 \cdot 35$ \\
Hydroxy fatty acids & & & \\
$\mathrm{C}_{18: 0} 3-\mathrm{OH}$ & $0 \cdot 75$ & $0 \cdot 55$ & $1 \cdot 47$ \\
Summed features & & & \\
SF2 & $1 \cdot 93$ & $3 \cdot 45$ & $2 \cdot 14$ \\
SF3 & $6 \cdot 45$ & $1 \cdot 38$ & $0 \cdot 38$ \\
SF7 & - & - & $0 \cdot 87$ \\
\hline
\end{tabular}

${ }^{*}$ Summed features represent groups of two or three fatty acids which could not be separated by GLC with the MIDI system. SF2, $\mathrm{C}_{14: 0}$ $3-\mathrm{OH} / \mathrm{C}_{16: 1}$ iso I; SF3, iso- $\mathrm{C}_{15: 0} 2-\mathrm{OH} / \mathrm{C}_{16: 1} \omega 7 c$; SF7, $\mathrm{C}_{19: 1} \omega 6 c$ l unknown ECL $18 \cdot 846$. 
shown). Minor quantitative differences in amounts of $\mathrm{C}_{19: 0}$ cyclo $\omega 8 c$ and summed feature 7 were observed between our isolate, S. aggregata DSM $13394^{\mathrm{T}}$ and S. stellulata DSM $5886^{\mathrm{T}}$. The presence of $\mathrm{C}_{18: 1} \omega 7 \mathrm{c}$ as the predominant fatty acid and Q-10 as the dominant lipoquinone are characteristics of members of the Alphaproteobacteria (Uchino et al., 1998; Martínez-Cánovas et al., 2004). The coxL gene was amplified and then sequenced bidirectionally. Inferred amino acid sequences derived from partial sequence of $\mathrm{CO}$ dehydrogenase form I (GenBank accession no. AY753548) and form II (AY753549) large subunits of strain mano18 ${ }^{\mathrm{T}}$ were compared with corresponding sequences from the GenBank database. coxL sequences of strain mano $18^{\mathrm{T}}$ showed the highest identity (95-97\%) with S. aggregata DSM $13394^{\mathrm{T}}$ and S. stellulata DSM $5886^{\mathrm{T}}$. Strain mano $18^{\mathrm{T}}$ synthesizes BChl $a$ to grow photosynthetically under aerobic conditions, as judged by employing PCR amplification of a phototrophism-related gene ( $p u f M$, encoding the $M$ subunit of the photosynthetic reaction centre, universally distributed among aerobic phototrophic bacteria; Achenbach et al., 2001).

Cells of strain mano $18^{\mathrm{T}}$ are Gram-negative rods, do not form spores and are motile by means of polar flagella. It is halophilic and requires sodium ions for growth. It is able to grow under anaerobic conditions by nitrate reduction. King (2003) showed that all known strains of Stappia oxidize CO and possess a gene for ribulose-1,5-bisphosphate carboxylase/oxygenase, which plays a central role in lithotrophic carbon fixation. Oxidization of $\mathrm{CO}$ by strain $\operatorname{mano} 18^{\mathrm{T}}$ was not examined; however, the presence of $\operatorname{coxL}$ genes showing highest sequence similarity to those from members of the genus Stappia suggests that strain mano $18^{\mathrm{T}}$ may oxidize $\mathrm{CO}$, like other species in the genus Stappia. Therefore, on the basis of the data presented, strain mano $18^{\mathrm{T}}$ should be placed in the genus Stappia as a representative of a novel species, for which the name Stappia marina sp. nov. is proposed.

\section{Description of Stappia marina sp. nov.}

Stappia marina (ma.ri'na. L. fem. adj. marina of the sea, marine).

Cells are Gram-negative, $1 \cdot 3-2 \cdot 0 \mu \mathrm{m}$ in length and $0 \cdot 6-0.8 \mu \mathrm{m}$ in diameter, do not form spores and are motile by means of polar flagella. Cells occasionally form rosette-like aggregates. It is able to grow by nitrate reduction. Oxidase- and catalase-positive. Urease, aesculin hydrolysis and $\beta$-galactosidase are positive. Acid production from glucose, indole production from tryptophan, arginine dihydrolase and gelatin hydrolysis are negative. Halophilic; requires sodium ions for growth. Optimal $\mathrm{NaCl}$ concentration for growth is $3 \%(\mathrm{w} / \mathrm{v})$. Optimal growth temperature is $25{ }^{\circ} \mathrm{C}$ on MA. Nitrate is reduced to nitrite, but is not reduced to nitrogen gas. Q-10 is the predominant respiratory quinone. The principal cellular fatty acids are $\mathrm{C}_{18: 1} \omega 7 c$ (58.4\%), 11-methyl $\mathrm{C}_{18: 1} \omega 7 c(9 \cdot 0 \%), \mathrm{C}_{18: 0}(8 \cdot 0 \%)$ and $\mathrm{C}_{20: 1} \omega 7 c(7 \cdot 8 \%)$. The $\mathrm{G}+\mathrm{C}$ content of the DNA of the type strain is $59 \cdot 7 \mathrm{~mol} \%$. Cells synthesize $\mathrm{BChl}$ under aerobic conditions.

The type strain, strain mano $18^{\mathrm{T}}\left(=\mathrm{KCTC} 12288^{\mathrm{T}}=\mathrm{DSM}\right.$ $17023^{\mathrm{T}}$ ), was isolated from a sample of a tidal flat obtained in Dae-Chun, Chung-Nam, Korea.

\section{Acknowledgements}

This work was supported by grant BDM0200524, grant NNM0100512 and the KRIBB Research Initiative Program.

\section{References}

Achenbach, L. A., Carey, J. \& Madigan, M. T. (2001). Photosynthetic and phylogenetic primers for detection of anoxygenic phototrophs in natural environments. Appl Environ Microbiol 67, 2922-2926.

Ahrens, R. (1968). Taxonomische Untersuchungen an sternbildenden Agrobacterium-Arten aus der westlichen Ostsee. Kiel Meeresforsch 24, 147-173 (in German).

Baumann, P., Baumann, L. \& Mandel, M. (1971). Taxonomy of marine bacteria: the genus Beneckea. J Bacteriol 107, 268-294.

Beja, O., Suzuki, M. T., Heidelberg, J. F., Nelson, W. C., Preston, C. M., Hamada, T., Eisen, J. A., Fraser, C. M. \& DeLong, E. F. (2002). Unsuspected diversity among marine aerobic anoxygenic phototrophs. Nature 415, 630-633.

Collins, M. D. \& Jones, D. (1981). Distribution of isoprenoid quinone structural types in bacteria and their taxonomic implications. Microbiol Rev 45, 316-354.

King, G. M. (2003). Molecular and culture-based analyses of aerobic carbon monoxide oxidizer diversity. Appl Environ Microbiol 69, $7257-7265$

Kusuda, R., Kawai, K., Salati, F., Banner, C. R. \& Fryer, J. L. (1991). Enterococcus seriolicida sp. nov., a fish pathogen. Int J Syst Bacteriol 41, 406-409.

Lee, J.-S., Lee, K. C., Pyun, Y.-R. \& Bae, K. S. (2003). Arthrobacter koreensis sp. nov., a novel alkalitolerant bacterium from soil. Int J Syst Evol Microbiol 53, 1277-1280.

Martínez-Cánovas, M. J., Quesada, E., Martínez-Checa, F., del Moral, A. \& Béjar, V. (2004). Salipiger mucescens gen. nov., sp. nov., a moderately halophilic, exopolysaccharide-producing bacterium isolated from hypersaline soil, belonging to the $\alpha$-Proteobacteria. Int J Syst Evol Microbiol 54, 1735-1740.

Rüger, H.-J. \& Höfle, M. G. (1992). Marine star-shaped-aggregateforming bacteria: Agrobacterium atlanticum sp. nov.; Agrobacterium meteori sp. nov.; Agrobacterium ferrugineum sp. nov., nom. rev.; Agrobacterium gelatinovorum sp. nov., nom. rev.; and Agrobacterium stellulatum sp. nov., nom. rev. Int J Syst Bacteriol 42, 133-143.

Sambrook, J., Fritsch, E. F. \& Maniatis, T. (1989). Molecular Cloning: a Laboratory Manual, 2nd edn. Cold Spring Harbor, NY: Cold Spring Harbor Laboratory.

Sasser, M. (1990). Identification of Bacteria by Gas Chromatography of Cellular Fatty Acids. Newark, DE: MIDI Inc.

Shin, Y. K., Lee, J.-S., Chun, C. O., Kim, H.-J. \& Park, Y.-H. (1996). Isoprenoid quinone profiles of the Leclercia adecarboxylata KCTC $1036^{\mathrm{T}}$. J Microbiol Biotechnol 6, 68-69.

Smibert, R. M. \& Krieg, N. R. (1994). Phenotypic characterization. In Methods for General and Molecular Bacteriology, pp. 607-654. Edited 
by P. Gerhardt, R. G. E. Murray, W. A. Wood \& N. R. Krieg. Washington, DC: American Society for Microbiology.

Stapp, C. \& Knösel, D. (1954). Zur Genetik sternbildender Bakterien. Zentralbl Bakteriol Parasitenkd Infektionskr Hyg Abt 2 108, 243-259 (in German).

Suzuki, T., Muroga, Y., Takahama, M. \& Nishimura, Y. (2000). Roseibium denhamense gen. nov., sp. nov. and Roseibium hamelinense sp. nov., aerobic bacteriochlorophyll-containing bacteria isolated from the east and west coasts of Australia. Int J Syst Evol Microbiol 50, 2151-2156.

Tamaoka, J. \& Komagata, K. (1984). Determination of DNA base composition by reversed-phase high-performance liquid chromatography. FEMS Microbiol Lett 25, 125-128.

Thompson, J. D., Gibson, T. J., Plewniak, F., Jeanmougin, F. \& Higgins, D. G. (1997). The CLUSTAL_X Windows interface: flexible strategies for multiple sequence alignment aided by quality analysis tools. Nucleic Acids Res 25, 4876-4882.

Uchino, Y., Hirata, A., Yokota, A. \& Sugiyama, J. (1998). Reclassification of marine Agrobacterium species: proposals of
Stappia stellulata gen. nov., comb. nov., Stappia aggregata sp. nov., nom. rev., Ruegeria atlantica gen. nov., comb. nov., Ruegeria gelatinovora comb. nov., Ruegeria algicola comb. nov., and Ahrensia kieliense gen. nov., sp. nov., nom. rev. J Gen Appl Microbiol 44, 201-210.

Willcox, M. D. P. (1996). Identification and classification of species within the Streptococcus sanguis group. Aust Dent J 41, 107-112.

Yoon, J.-H., Lee, S. T. \& Park, Y.-H. (1998). Inter- and intraspecific phylogenetic analysis of the genus Nocardioides and related taxa based on 16S rDNA sequences. Int J Syst Bacteriol 48, 187-194.

Yoon, J.-H., Kim, H., Kim, I.-G., Kang, K. H. \& Park, Y.-H. (2003a). Erythrobacter flavus sp. nov., a slight halophile from the East Sea in Korea. Int J Syst Evol Microbiol 53, 1169-1174.

Yoon, J.-H., Kim, I.-G., Kang, K. H., Oh, T.-K. \& Park, Y.-H. (2003b). Bacillus marisflavi sp. nov. and Bacillus aquimaris sp. nov., isolated from sea water of a tidal flat of the Yellow Sea in Korea. Int J Syst Evol Microbiol 53, 1297-1303.

Yoon, J.-H., Weiss, N., Kang, K. H., Oh, T.-K. \& Park, Y.-H. (2003c). Planococcus maritimus sp. nov., isolated from sea water of a tidal flat in Korea. Int J Syst Evol Microbiol 53, 2013-2017. 